\title{
PENGARUH PROGRAM TAHFIDZUL QUR'AN DAN MOTIVASI BELAJAR TERHADAP PRESTASI AKADEMIK MAHASISWA: Studi Pada Mahasiswa PKD dan PKP Universitas Djuanda Bogor
}

\author{
Muhammad Khoiruddin \\ Dosen Prodi MPI FKIP Universitas Djuanda Bogor \\ masudin2728@gmail.com
}

Received: 08-05-2018, Accepted: 13-08-2018, Published: 03-09-2018

\begin{abstract}
Abstrack
This study aims to gain an understanding of empirical data on the relationship Tahfidzul Qur'an program and learning Motivation, both individually and together with student achievement cadre program of da'wah (PKD) and agricultural cadre program (PKP) in University Djuanda Bogor. The research hypothesis is (1) There is a close and significant influence of Tahfidzul Qur'an program toward academic achievement of PKD and PKP students of Djuanda University Bogor (2) There is a close and significant influence of learning motivation to student achievement PKD and PKP Universitas Djuanda Bogor. (3) There is influence between Qur'an Tahfidzul program and learning motivation toward student academic achievement. In this study the authors use a survey method with a correlational approach that is implemented at the University of Djuanda Bogor involving students PKD and PKP. The data were collected by observation, interview, questionnaire, and documentary study. Data analysis using correlation analysis with correlation technique product moment formula.
\end{abstract}

\begin{abstract}
Abstrak
Penelitian ini bertujuan untuk mendapatkan pemahaman data-data empirik mengenai hubungan program Tahfidzul Qur'an dan motivasi belajar, baik dilakukannya secara sendiri-sendiri maupun secara bersama-sama dengan Prestasi Akademik Mahasiswa program kader dakwah (PKD) dan program kader pertanian (PKP) di Universitas Djuanda Bogor. Hipotesis penelitian ialah (1) Terdapat pengaruh yang erat dan signifikan dari program Tahfidzul Qur'an terhadap Prestasi Akademik Mahasiswa PKD dan PKP Universitas Djuanda Bogor (2) Terdapat pengaruh yang erat dan signifikan dari motivasi belajar terhadap Prestasi Akademik Mahasiswa PKD dan PKP Universitas Djuanda Bogor. (3) Terdapat pengaruh antara program Tahfidzul Qur'an dan motivasi belajar terhadap Prestasi Akademik Mahasiswa. Dalam penelitian ini penulis menggunakan metode survei dengan pendekatan korelasional yang dilaksanakan di Universitas Djuanda Bogor dengan melibatkan Mahasiswa PKD dan PKP. Pengumpulan data dilakukan dengan observasi, wawancara, angket, dan studi dokumenter. Analisis data menggunakan analisis korelasional dengan teknik korelasi rumus product moment.
\end{abstract}

Keywords: tahfidzul Qur'an, learning motivation, academic achievement. 


\section{PNDAHULUAN}

Dalam situasi belajar yang sifatnya kompleks dan menyeluruh serta melibatkan interaksi beberapa komponen, sering ditemukan mahasiswa yang tidak dapat meraih prestasi akademik yang setara dengan kemampuan intelegensinya. Karena pada dasarnya prestasi akademik merupakan hasil interaksi dari berbagai faktor yang berbeda antara satu individu dengan individu lainnya. ${ }^{1}$ Namun di sisi lain tidak jarang ditemukan seorang mahasiswa mampu meraih prestasi akademik yang sangat memuaskan, di samping tingkat intelegensi yang memadai, juga faktor-faktor pendukung lainnya yang ikut berperan mendorong serta meningkatkan prestasi akademiknya.

Universitas Djuanda Bogor adalah salah satu dari perguruan tinggi di dalam mendorong dan meningkatkan hasil prestasi akademik mahasiswanya dengan menerapkan beberapa program yang relevan untuk meningkatan prestasi akademik mahasiswanya, baik berkaitan langsung dengan kegiatan perkuliahan yang bersifat formal ataupun kegiatan-kegiatan yang bersifat informal/ekstra, misalnya berupa pembinaan-pembinaan dan

1 Baiquni. (2012 Dsember 25). Intelegensia bukan satu-satunya. dapat dibuka Pada situs http://www.e-psikologi.com/intelegensia/acs34/html. pelatihan-pelatihan salah satunya adalah pembinaan Tahfidzul Qur'an sebagai salah satu sarana dan motivasi untuk meningkatkan prestasi akademik mahasiswanya.

Tidak bisa lepas dari Al-Qur'an sebagai panutan, maka sebagai seorang muslim harus bisa mempelajari dan mengamalkan isi dan kandungan Al-Qur'an tersebut. bagi Universitas Djuanda Bogor Tahfidzul Qur'an merupakan bagian dari silabus lokal lembaga, dikhususkan bagi mahasiswa dan mahasiswi yang mendapatkan beasiswa selama menempuh studi di Universitas Djuanda Bogor.

Tahfizhul Qur'an adalah kegiatan menghafalkan Al-Qur'an yang dilakukan oleh seseorang dengan tujuan utama untuk mendekatkan diri kepada Allah S.W.T. Kegiatan Tahfizh merupakan bagian dari agenda umat Islam yang telah berlangsung secara turun temurun semenjak Al-Qur'an diturunkan kepada Nabi Muhammad S.A.W. sampai saat ini dan sampai waktu yang akan datang nanti, sebagaimana firman Allah S.W.T. dalam Surah alHijr/15: 9:

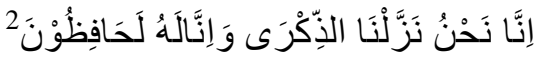

\footnotetext{
${ }^{2}$ Kementerian Agama RI. (2010). Al-Qur'an
} dan Tafsirnya. Ciawi: LPQ Kemenag RI. jilid V hlm. 208. 
Sungguh Kami-lah yang menurunkan Al-Qur'an dan Kami pula yang akan menjaganya.

Penggunaan kata "Kami" dalam ayat tersebut adalah untuk menunjuk Allah S.W.T. Antara lain bertujuan mengisyaratkan adanya keterlibatan selain Allah S.W.T. dalam proses penurunan dan pemeliharaan Al-Qur'an, yakni keterlibatan malaikat Jibril A.S. pada proses turunnya dan keterlibatan sekian banyak makhlukNya, antara lain manusia dalam pemeliharaanya. Di samping sebagai nilai ibadah kegiatan menghafal Al-Qur'an juga merupakan rangkaian dari memelihara keaslian ayat-ayat Al-Qur'an.

Selain Program Tahfidzul Qur'an, motivasi belajar adalah sebagai pendorong, pengerak, dan sebagai suatu pengarah terhadap prestasi akademik mahasiswa. Lembaga pendidikan, sebagai wadah tempat berkumpulnya agen-agen perubahan sosial dan segala perangkatnya, haruslah memiliki prinsip kebersamaan atau kerjasama yang baik antar lembaga dan anggota serta orang-orang yang berkepentingan di dalamnya, tanpa kerjasama yang baik, semua cita-cita yang menjadi tujuan berdirinya lembaga pendidikan ibarat asap yang terlihat tebal akan tetapi mudah sirna dengan sendirinya.
Motivasi adalah perubahan energi dalam diri seseorang yang ditandai dengan munculnya feeling dan didahului dengan tanggapan terhadap adanya tujuan. Pada intinya bahwa motivasi merupakan kondisi psikologis yang mendorong seseorang untuk melakukan sesuatu. Dalam kegiatan belajar, motivasi sangat diperlukan, sebab seseorang yang tidak mempunyai motivasi dalam belajar, tidak akan mungkin melakukan aktivitas belajar.

Motivasi belajar adalah proses internal yang mengaktifkan, memandu, dan mempertahankan perilaku dari waktu ke waktu. Individu termotivasi karena berbagai alasan yang berbeda, dengan intensitas yang berbeda. Sebagai misal, seorang mahasiswa dapat tinggi motivasinya untuk menghadapi tes ilmu sosial dengan tujuan mendapatkan nilai tinggi (motivasi ekstrinsik) dan tinggi motivasinya menghadapi tes matematika karena tertarik dengan mata pelajaran tersebut (motivasi intrinsik).

Motivasi belajar mahasiswa dapat didefinisikan sebagai suatu keadaan dalam diri mahasiswa yang mendorong dan mengarahkan perilakunya kepada tujuan yang ingin dicapainya dalam mengikuti pendidikan tinggi. Idealnya, tujuan mahasiswa dalam mengikuti pendidikan 
tinggi adalah untuk menguasai bidang ilmu yang dipelajarinya.

Menjadi sebuah kajian yang menarik untuk diteliti motivasi belajar mahasiswa yang berbeasiswa dalam menempuh studinya, apakah antara program Tahfidzul Qur'an dan motivasi belajar mahasiswa mempunyai pengaruh yang sangat kuat terhadap hasil prestasi akademik mahasiswa, ataukah sebaliknya menjadikan sebuah kemunduran dalam meraih prestasi akademik yang maksimal.

\section{KAJIAN TEORI}

\section{Program Tahfidzul Qur'an}

Menghafal Al-Qur'an terdiri dari kata "menghafal" dan "Al-Qur'an". Dalam Kamus Besar Bahasa Indonesia menghafal adalah berusaha meresapkan ke dalam pikiran agar selalu ingat. ${ }^{3}$

Al-Hifz (hafalan) secara bahasa (etimologi) adalah lawan dari lupa, yaitu selalu ingat dan sedikit lupa. Dalam kaitan ini, menghafal Al-Qur'an, memeliharanya serta menalarnya haruslah memperhatikan tiga unsur pokok berikut; (a) menghayati bentuk-bentuk visual sehingga bisa diingat kembali meskipun tanpa kitab, membacanya secara rutin ayat-ayat yang dihafalkan dan (c) mengingat-ingatnya. ${ }^{4}$

3 Pusat Pembinaan dan Pengembangan Bahasa Depdikbud. (1989). Kamus Besar Bahasa Indonesia. Jakarta: Balai Pustaka. hlm. 291.

${ }^{4}$ Lihat Abdurrab Nawabuddin dan Bambang Saiful Ma'arif. (2015). Teknik Menghafal Al-Quran.
Dari kedua prinsip tersebut di atas, maka dapat dikatakan bahwa penghafal AlQur'an adalah orang yang melakukan suatu aktifitas mencamkan dengan sengaja ayatayat Al-Quran, kemudian memelihara dan menjaganya dari perubahan, penyimpangan, penambahan serta pengurangan.

\section{Motivasi Belajar}

Motivasi secara umum mempunyai pengertian, suatu kebijaksanaan oleh pimpinan perusahaan sebagai pendorong kerja karyawan agar dapat bekerja lebih produktif guna mencapai tujuan yang diharapkan perusahaan.

Pengertian motivasi menurut Ranupandojo dan Husnan, menyatakan bahwa motivasi adalah merupakan proses untuk mencoba mempengaruhi seseorang agar melakukan sesuatu yang kita inginkan. ${ }^{5}$

Mc. Clelland's achievment Motivation Theory atau Teori Motivasi Prestasi dikemukakan oleh David Mc.Clelland. Teori ini berpendapat bahwa seseorang mempunyai cadangan energi potensial. Energi ini akan dimanfaatkan oleh seseorang karena didorong oleh kekuatan motif dan kebutuhan dasar yang

Bandung: Sinar Baru Algensindo. hlm. 23-25; dan Muhaimin Zen. (1998). Tata Cara, Problematika Menghafal Al-Quran dan Petunjuk-petunjuknya, Jakarta: Litera Antar Nusa. hlm. 21-40.

${ }^{5}$ Ranupandojo dan Husnan. (1990). Psikologi Motivasi. Yogyakarta: LKIS. hlm. 197. 
terlibat, harapan keberhasilannya, dan nilai insentif yang terlekat pada tujuan. Mc. Clelland mengelompokan 3 kebutuhan manusia yang dapat memotivasi gairah bekerja seseorang, yaitu ${ }^{6}$ :

a) Kebutuhan akan prestasi (need for achievment).

b) Kebutuhan akan afiliasi (need for affiliation).

c) Kebutuhan akan kekuasaan (need for power).

Motivasi belajar mempunyai tujuan untuk memberikan perubahan yang signifikan bagi peserta didik. Menurut S. Nasution, motivasi mempunyai tujuan sebagai berikut: ${ }^{7}$

a) Mendorong timbulnya kelakuan atau perbuatan, tanpa adanya motivasi maka tidak akan timbul suatu perubahan, seperti belajar.

b) Motivasi berfungsi sebagai pengarah perbuatan untuk mencapai tujuan.

c) Motivasi berfungsi sebagai penggerak, dimana akan menentukan lambat atau cepatnya suatu pekerjaan.

Dengan meminjam berbagai definisi tentang motivasi, maka motivasi belajar mahasiswa dapat didefinisikan sebagai suatu keadaan dalam diri mahasiswa yang mendorong dan mengarahkan perilakunya kepada tujuan yang ingin dicapainya dalam mengikuti pendidikan tinggi. Idealnya, tujuan mahasiswa dalam mengikuti

6 David .C McClelland. (1961). The Achieving Society, New York: Van Nostrand Reinhold. hlm. 63-73.

7 S. Nasution. (2000). Dikdatif Asas-Asas Mengajar, Jakarta: Bumi Aksara. hlm. 76. pendidikan tinggi adalah untuk menguasai bidang ilmu yang dipelajarinya.

\section{Prestasi Akademik}

Prestasi pada umumnya dihubungkan dengan hasil yang dicapai seseorang baik dalam bidang pekerjaan maupun dalam bidang pendidikan. Seseorang dikatakan berprestasi baik apabila hasil usaha yang dicapai mendekati apa yang diharapkan. Sebaliknya, prestasi itu dikatakan menurun apabila hasil usahanya tidak sesuai dengan tujuan yang diharapkan. Dalam Kamus Besar Bahasa Indonesia, prestasi belajar adalah penguasaan pengetahuan/ keterampilan yang dikembangkan oleh mata pelajaran lazimnya ditunjukkan dengan nilai/ angka nilai yang diberikan guru. $^{8}$

Menurut Nasrun Harahap dkk, prestasi didefinisikan sebagai suatu penilaian pendidikan tentang perkembangan dan kemajuan murid yang berkenaan dengan penguasaan bahan pelajaran yang disajikan kepada mereka serta nilai-nilai yang terdapat dalam kurikulum. ${ }^{9}$

Sedang menurut Mas'ud Khasan Abdul Qohar, prestasi adalah apa yang telah dapat diciptakan, hasil pekerjaan, hasil yang

\footnotetext{
${ }^{8 .}$ Kamus Besar Bahasa Indonesia, hlm. 700.

9. Syaiful Bahri Djamarah. (1994). Prestasi Belajar Dan Kompetensi Guru, Surabaya: Usaha Nasional. hlm. 21.
} 
menyenangkan hati yang diperoleh dengan jalan keuletan kerja. ${ }^{10}$

Dari beberapa pengertian di atas dapat dipahami bahwa prestasi adalah hasil dari sesuatu yang telah dikerjakan, diciptakan, yang menyenangkan hati, yang diperoleh dengan jalan keuletan kerja baik secara individual maupun kelompok dalam bidang kegiatan tertentu. Prestasi pada dasarnya adalah hasil yang diperoleh dari suatu aktifitas.

Sedangkan pengertian prestasi akademik adalah hasil yang diperoleh berupa kesan-kesan yang mengakibatkan perubahan dalam diri individu sebagai hasil dari aktivitas dalam belajar.

Prestasi akademik juga dapat digunakan sebagai masukan untuk perbaikan kurikulum. Banyak cara untuk mengukur prestasi akademik. Pengajar dapat melakukannya dengan cara mengajukan pertanyaan lisan, memberikan pekerjaan rumah/tugas tertulis atau melihat penampilan aktual dari tugas keterampilan dan tes tertulis. Namun yang paling umum dilakukan adalah melalui tes tertulis. ${ }^{11}$

Beberapa faktor yang mendukung keberhasilan prestasi akademik

10. Syaiful Bahri Djamarah. (1994). hlm. 20.

11 Endang Tatiana dan Budi W. Soetcipto. (2005). Model Prestasi Akademik Mahasiswa: Potensi Akademik dan Gaya Belajar. Jurnal USAHAWAN, 04 TH. XXXIV. hlm. 5. sebagaimana di atas, maka beberapa faktor yang dikemukakan di atas merupakan faktor-faktor yang baik secara langsung maupun tidak langsung memiliki hubungan dengan keberhasilan prestasi akademik setiap mahasiswa.

Atas dasar kerangka berfikir di atas, maka penulis mencoba menggambarkannya dalam sebuah bagan korelasi hubungan antar variabel sebagai berikut:

Gambar Korelasi antar Variabel

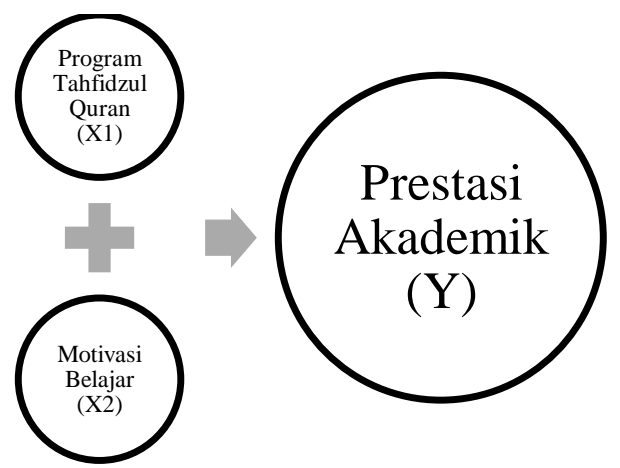

\section{Kerangka Berfikir}

Prestasi Akademik adalah suatu bukti keberhasilan belajar atau kemampuan seorang mahasiswa dalam melakukan kegiatan belajarnya yang dituangkan dalam Indeks Prestasi Kumulatif (IPK). Namun prestasi akademik mahasiswa tidak hanya diperoleh dari hasil belajar di bangku kuliah, menyelesaikan tugas-tugas yang dibebankan kepada setiap mahasiswa, akan tetapi keberadaan prestasi akademik juga dipengaruhi oleh hal-hal lain selama mahasiswa menempuh studi. 
Sehubungan dengan meningkatkan mutu pendidikan dan prestasi belajar maka perlu diadakan kegiatan-kegiatan yang mendukung terhadap peningkatan mutu pendidikan dan prestasi belajar. Upaya meningkatkan mutu pendidikan dan kualitas pendidikan, maka dapat diawali dengan memperhatikan prestasi belajar siswa.

Sehubungan dengan peningkatan prestasi Akademik Mahasiswa Universitas Djuanda Bogor, khususnya mahasiswa yang dalam menempuh studinya mendapatkan beasiswa baik dari yayasan maupun instansi pemerintah dalam hal ini adalah mahasiswa PKD dan PKP, maka Lembaga Universitas Djuanda menerapkan program hafalan AlQur`an. Kewajiban menghafal Al-Qur`an merupakan upaya yang dilakukan dalam meningkatkan pengetahuan mahasiswa tentang Al-Qur`an guna meningkatkan ghirah untuk memahami dan mengamalkan isi kandungan Al-Qur'an.

Mahasiswa PKD dan PKP selama menempuh pendidikan di Universitas Djuanda Bogor yang hampir seluruhnya merupakan mahasiswa yang menerima bantuan beasiswa penuh selama studinya, oleh karena itu penulis menduga adanya program kewajiban menghafal Al-Qur'an dan motivasi belajar dari predikat Mahasiswa ber-beasiswa apakah mampu meningkatkan prestasi akademiknya ataukah tidak.

\section{Hipotesa}

Hipotesis adalah jawaban sementara terhadap rumusan masalah penelitian, dimana rumusan masalah penelitian telah dinyatakan dalam bentuk pernyataan.

Dikatakan sementara karena jawaban berdasarkan pada teori yang relevan, belum berdasarkan pada fakta-fakta empiris yang diperoleh melalui pengumpulan data. Jadi hipotesis juga dapat dinyatakan sebagai jawaban teoritis terhadap rumusan masalah penelitian, belum sebagai jawaban empiris. $^{12}$

Hipotesis pada permasalahan tersebut dapat dinyatakan sebagai berikut;

$$
\text { 1. } \begin{aligned}
\mathrm{H}_{\mathrm{O}} & : \rho \mathrm{x}_{1}=0 \\
\mathrm{H}_{\mathrm{I}} & : \rho \mathrm{x}_{1}>0
\end{aligned}
$$

- Tidak terdapat pengaruh antara program Tahfidzul Qur'an dengan prestasi akademik mahasiswa

- Terdapat pengaruh antara program Tahfidzul Qur'an dengan prestasi akademik mahasiswa

$$
\text { 2. } \begin{aligned}
\mathrm{H}_{\mathrm{O}} & : \rho \mathrm{x}_{2}=0 \\
\mathrm{H}_{\mathrm{I}} & : \rho \mathrm{x}_{2}>0
\end{aligned}
$$

- Tidak terdapat pengaruh antara motivasi belajar dengan prestasi akademik mahasiswa

12 Iskandar. (2009). Metodologi Penelitian Pendidikan dan Sosial (Kualitatif dan Kuantitatif). Jakarta: Gaung Persada Press. hlm. 56. 
- Terdapat pengaruh antara motivasi belajar dengan prestasi akademik mahasiswa

$$
\text { 3. } \begin{aligned}
\mathrm{H}_{\mathrm{O}}: \mathrm{R}_{12} & =0 \\
\mathrm{H}_{\mathrm{I}}: \mathrm{R}_{12} & >0
\end{aligned}
$$

- Tidak terdapat pengaruh antara program Tahfidzul Qur'an dan motivasi belajar secara bersama-sama dengan prestasi akademik mahasiswa

- Terdapat pengaruh antara program Tahfidzul Qur'an dan motivasi belajar secara bersama-sama dengan prestasi akademik mahasiswa

Dari hipotesis di atas, penulis memiliki dugaan sementara bahwa terdapat pengaruh positif dari program Tahfidzul Qur'an dan motivasi belajar mahasiswa PKD dan PKP terhadap prestasi akademik mahasiswa PKP dan PKD.

Untuk itu, peneliti sepakat dengan pernyataan $\mathrm{H}_{\mathrm{I}}$ di atas. Adapun untuk kebenarannya, maka akan dibuktikan melalui hasil penelitian yang dilakukan di Universitas Djuanda Bogor.

\section{Objek Penelitian}

Objek penelitian ini adalah Mahasiswa Program Kader Dakwah (PKD). tujuan utama dari PKD adalah untuk mengkader generasi-generasi yang tangguh dan siap mengemban amanat ketika terjun dimasyarakat, khususnya di lingkungan Universitas Djuanda Bogor. ${ }^{13}$

13 Wawancara dengan Wakil Rektor I Universitas Djuanda Bogor Dr. H. Endin Mujahidin.
Mahasiswa Program Kader Pertanian (PKP) adalah mahasiswa Universitas Djuanda yang mendapatkan beasiswa dari Pemerintahan Propinsi Jawa Barat secara menyeluruh dalam masa studinya di Universitas Djuanda, berawal dari hibah Departemen Sosial RI dengan dibangunnya Rumah Susun Mahasiswa (RUSUNAWA) pada tahun akademik 2008/2009, sehingga untuk mengoptimalisasikan penggunaan Rusunawa tersebut Universitas Djuanda menggandeng Pemprov Jawa Barat untuk memberikan beasiswa kepada mahasiswa yang belajar di Universitas Djuanda Bogor. ${ }^{14}$

Pola pembinaan Mahasiswa PKP adalah sama dengan mahasiswa PKD, mereka tinggal di asrama yang sama, dengan kegiatan-kegiatan yang ditentukan oleh lembaga, sebagaimana kegiatan yang dilakukan pada pola pendidikan di Pondok Pesantren Modern Gontor Ponorogo. Hal ini diharapkan agar mahasiswa PKP akan siap terjun di tengah-tengah masyarakat sesuai dengan ilmu yang ditekuni saat kuliah di Universitas Djuanda Bogor.

Pola pembinaan yang demikian ini adalah mengacu terhadap visi dan misi

14 Wawancara dengan Kepala Biro Pembinaan Mahasiswa dan Alumni (BPMA) Universitas Djuanda Bogor, 25 Mei 2013 
Universitas Djuanda Bogor, khususnya implementasi dan penerapan nilai-nilai tauhid dalam kehidupan beragama, bernegara, dan bermasyarakat. sehingga lulusan dari PKP menjadi lulusan yang kuat iman, intlektual, dan berakhlaq.

\section{METODE PENELITIAN}

a. Jenis Penelitian

Berdasarkan jenis datanya, penelitian ini termasuk penelitian kuantitatif. Menurut Sugiyono, penelitian kuantitatif dapat diartikan sebagai metode penelitian yang berdasarkan pada filsafat positivisme, digunakan untuk meneliti pada populasi atau sampel tertentu, pengumpulan data menggunakan instrument penelitian, analisis data bersifat kuantitatif/statistik, dengan tujuan untuk menguji hipotesis yang telah ditetapkan.

Filsafat positivisme memandang realitas/ gejala/ fenomena itu dapat diklasifikasikan, relatif tetap, konkrit, teramati, terukur, dan hubungan gejala bersifat sebab akibat. ${ }^{15}$

Untuk memperoleh gambaran yang jelas tentang jenis penelitian yang digunakan tidak terlepas dari permasalahan yang akan diteliti. Rancangan yang digunakan dalam penelitian ini adalah

15 Sugiyono. (2006). Metode Penelitian Kuantitatif Kualitatif dan $R \quad \& \quad D$. Bandung: Alfabeta. hlm. 8 . rancangan analisa korelasional (problema untuk mencari hubungan antara dua fenomena) tepatnya korelasi sebab akibat, yaitu pengungkapan pengaruh variabel independen dengan variabel dependen.

Metode yang digunakan dalam penelitian ini adalah metode survei dengan pendekatan korelasional. Survei adalah pengamatan atau penyelidikan yang kritis untuk mendapatkan keterangan yang terang dan baik terhadap suatu persoalan tertentu dan di dalam suatu daerah tertentu. ${ }^{16}$ Metode survei merupakan penelitian yang mengambil sampel dari populasi dan menggunakan kuisioner atau angket sebagai alat pengumpul data yang pokok.

Sedangkan pendekatan koresional adalah pendekatan dalam penelitian yang pada pelaksanaannya menggunakan teknik analisis yang dinamakan korelasi. Teknik analisa korelasional adalah tehnik analisa statistik mengenai hubungan antara dua variabel atau lebih. ${ }^{17}$

\section{b. Variabel Penelitian}

Dalam penelitian ini penulis menguji hubungan program tahfidzul Qur'an dan motivasi belajar dengan prestasi akademik

${ }^{16}$ S. Margono. (2004). Metodologi Penelitian Pendidikan. Jakarta: Rineka Cipta. hlm. 29.

${ }^{17}$ Anas Sudijono. (2000). Pengantar Statistik Pendidikan. Jakarta: Raja Grafindo Persada. hlm. 175. 
mahasiswa PKD dan PKP Universitas Djuanda Bogor.

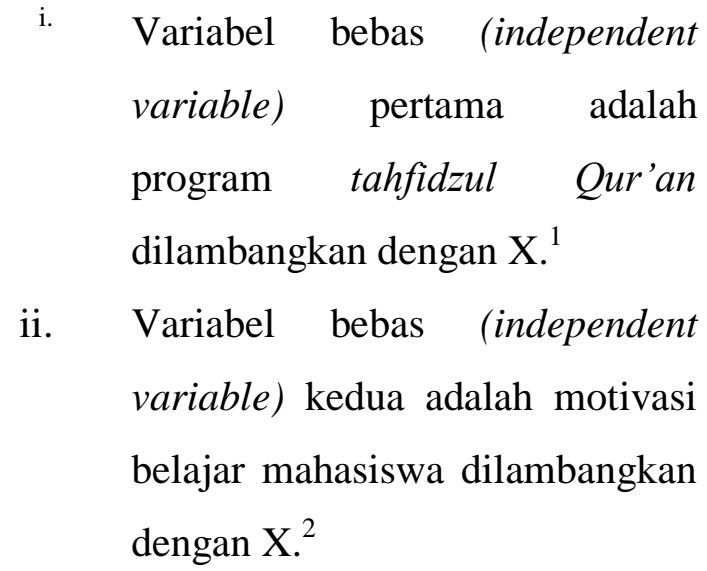

iii. Variable terikat (dependent variable) adalah prestasi akademik mahsiswa PKD dan PKP Universitas Djuanda Bogor.

\section{c. Instrumen dan Pengumpulan Data}

Pada prinsipnya meneliti adalah melakukan pengukuran, maka harus ada alat ukur yang baik. Alat ukur dalam penelitian biasanya dinamakan instrument penelitian. Jadi instrumen penelitian adalah suatu alat yang digunakan mengukur fenomena alam maupun sosial yang diamati. Secara spesifik semua fenomena ini disebut variabel penelitian. ${ }^{18}$

$$
\text { Berdasarkan tekniknya, }
$$
pengumpulan data dilakukan dengan metode:

\section{a. Observasi (pengamatan)}

$$
\text { Menurut Suharsimi Arikunto }
$$

observasi atau yang disebut pula dengan

18 Sugiyono. (2006) Metode Penelitian Kuantitatif Kualitatif dan $R$ \& D. hlm.114. pengamatan meliputi kegiatan pemuatan perhatian terhadap sesuatu objek dengan menggunakan seluruh alat indra. ${ }^{19}$ Jadi observasi merupakan metode pengumpulan data yang menggunakan panca indera disertai dengan pencatatan secara perinci terhadap obyek penelitian.

Metode ini digunakan untuk memperoleh data misalnya tentang kondisi fisik, letak geografis, sarana dan prasarana, proses belajar mengajar, kegiatan ekstrakulikuler mahasiswa serta pola hidup di Universitas Djuanda Bogor.

Dalam metode observasi ini peneliti menggunakan cara observasi non sistematis, yaitu observasi yang dilakukan tanpa menggunakan instrumen penelitian.

\section{b. Interview (wawancara)}

Interview yang sering juga disebut dengan wawancara atau kuesioner lisan adalah sebuah dialog yang dilakukan oleh pewawancara (interviewer) untuk memperoleh informasi dari terwawancara (interviewee). ${ }^{20}$

Metode ini merupakan cara pengumpulan data yang pelaksanaanya dengan jalan berdialog atau tanya jawab sepihak mengenai persoalan-persoalan

19 Suharsimi Arikunto. (2002). Prosedur Penelitian Suatu Pendekatan Praktek. hlm.126.

${ }^{20}$ Suharsimi Arikunto. (2002). hlm. 132. 
yang terkait dengan judul penelitian untuk mendapatkan jawaban dari responden.

Metode ini juga digunakan untuk memperoleh tanggapan dari rektor, para dosen, atau para mahasiswa selama penerapan kegiatan menghafal Al-Quran dan hal-hal yang berkaitan dengannya. Selain hal tersebut metode ini juga digunakan untuk memperoleh data tentang Kampus Universitas Djuanda, mencakup sejarah, prestasi, dan lain-lain.

Interview yang dilakukan penulis ini memakai cara interview bebas terpimpin, artinya peneliti menggunakan pedoman interview sebagai instrumen pengumpulan data yang hanya merupakan garis besar tentang hal-hal yang akan ditanyakan.

c. Kuesioner (angket)

Kuesioner adalah sejumlah pertanyaan tertulis yang digunakan untuk memperoleh informasi dari responden dalam arti laporan tentang pribadinya, atau hal-hal yang diketahui. $^{21}$

Metode ini digunakan oleh penulis untuk memperoleh data tentang pengaruh hafalan Al-Quran dan motivasi belajar melalui responden dengan jalan menjawab kuesioner tertutup, yakni

\footnotetext{
${ }^{21}$ Suharsimi Arikunto. (2002). hlm. 128.
}

kuesioner yang telah disediakan jawabannya oleh peneliti sehingga responden tinggal memilih saja mana jawaban yang dirasa paling sesuai dengan pendapatnya.

Dalam hal ini peneliti memakai metode kuesioner langsung sebagai instrument penelitian, yaitu responden menjawab tentang dirinya. Dan dilihat dari bentuknya, kuesioner ini termasuk kuesioner pilihan ganda.

\section{d. Metode Analisa Data}

Teknik analisa data merupakan cara yang digunakan untuk menganalisis data yang diperoleh dari hasil penelitian. Dalam menganalisis tentang penelitian ini, peneliti menggunakan:

i. Deskriptif kualitatif

Teknik ini adalah analisis yang bersifat eksploratif bertujuan menggambarkan keadaan/ suatu fenomena tertentu, yang dalam hal ini adalah untuk mengungkap bagaimana gambaran kegiatan menghafal Al- Quran dan motivasi belajar mahasiswa Universitas Djuanda Bogor.

ii. Analisis data statistic

Dalam menganalisa, peneliti menggunakan teknik analisa korelasional, yaitu teknik analisa statistik mengenai hubungan antar dua variabel atau lebih. 
Berdasarkan tujuannya, teknik analisa korelasional memiliki tiga macam tujuan, yaitu;

1) Ingin mencari bukti apakah memang benar antara variable yang satu dengan yang lain terdapat hubungan/korelasi.

2) Ingin mengetahui apakah hubungan antar variabel itu (jika memang ada), termasuk hubungan yang kuat, cukup, ataukah lemah.

3) Ingin memperoleh kejelasan secara matematik, apakah hubungan antar variabel itu merupakan hubungan yang berarti atau meyakinkan (signifikan), ataukah hubungan yang tidak signifikan.

\section{e. Uji Validitas Data}

Sebuah data dikatakan valid apabila hasil penelitian terdapat kesamaan data yang terkumpul dengan data sesungguhnya terjadi pada obyek yang diteliti. ${ }^{22}$

Dalam penelitian kuantitatif, kriteria utama terhadap data hasil penelitian adalah valid, reliabel dan obyektif. Menurut Suharsimi Arikunto, "Validitas adalah suatu ukuran yang menunjukkan tingkat-tingkat kevalidan atau kesahihan sesuatu instrument. $^{23}$

22 Sugiyono. (2005). Statistik Untuk Penelitian. Bandung: CV. Alfabeta. hlm. 267.

23. Suharsimi Arikunto. (2006). Prosedur Penelitian. Jakarta: Rineka Cipta. hlm.120.
Untuk mengukur validitas konstruk digunakan metode internal konsistensi, yaitu mengukur besarnya koefisien korelasi antara tiap butir dengan semua butir pernyataan menggunakan rumus Korelasi Product Moment (Pearson). Diterima atau tidaknya suatu butir pernyataan ditentukan oleh besarnya nilai $r$ hitung yang dibanding dengan nilai $\mathrm{r}$ tabel ( $\mathrm{r}$ product moment) pada $\alpha=0,05$. Jika $r$ hitung $>\mathrm{r}$ tabel, maka instrument tersebut dinyatakan valid (sahih).

Hasil uji validitas dengan 30 orang responden uji coba (try out) pada masingmasing instrumen penelitian adalah sebagai berikut:

a) Validitas instrumen program Tahfidzul Qur'an

Dari 36 butir pernyataan tentang program Tahfidzul Qur'an, setelah dilakukan uji coba ternyata terdapat 5 butir pernyataan yang tidak valid, yaitu nomor 13, 15, 24, 28, dan 29 . Dengan demikian terdapat 31 butir pernyataan instrumen program Tahfidzul Qur'an dinyatakan valid, digunakan untuk pengumpulan data penelitian.

b) Validitas instrumen Motivasi Belajar Dari 32 butir pernyataan tentang motivasi belajar, setelah dilakukan uji coba ternyata terdapat 7 butir 
pernyataan yang tidak valid, yaitu nomor 2, 18, 20, 23, 28, 31, dan 32 . Dengan demikian terdapat 25 butir pernyataan instrumen motivasi belajar mahasiswa dinyatakan valid, digunakan untuk pengumpulan data penelitian.

\section{f. Uji Reabilitas Data}

Pengujian reabilitas instrumen dapat dilakukan secara eksternal maupun internal. Dalam hal ini pengujian akan diakukan secara Internal Consistency, yakni dilakukan dengan cara mencobakan instrument sekali saja. Hasil analisis dapat digunakan untuk memprediksi reabilitas instrumen. $^{24}$

Instrumen dapat dikatakan reliabel apabila instrumen tersebut cukup dapat dipercaya untuk digunakan sebagai alat pengumpulan data. Menurut Sugiyono, untuk data mencari reliabilitas maka dapat digunakan

Reliabilitas berkenaan dengan derajat konsistensi dan stabilitas data atau temuan. Ronny Kountur, menjelaskan: "Reliabilitas (reliability) berhubungan dengan konsistensi. Suatu instrumen penelitian disebut reliabel apabila instrumen tersebut konsisten dalam memberikan penilaian atas apa yang diukur. Jika hasil penilaian yang diberikan oleh instrument tersebut

${ }^{24}$ Anas Sudijono. (2000). Pengantar Statistik Pendidikan. hlm.146 konsisten memberikan jaminan, bahwa instrument tersebut dapat dipercaya". ${ }^{25}$

\section{Hasil dan Pembahasan}

\section{Uji Persyaratan Analisis}

Pengujian persyaratan analisis perlu dilakukan sebelum data dianalisis lebih lanjut. Pengujian persyaratan analisis yang dilakukan yaitu uji normalitas, linearitas dan homogenitas. Uji normalitas dilakukan karena berdasarkan metode penelitian, analisis data dalam penelitian ini menggunakan analisis regresi dan korelasi, sehingga galat taksiran persamaan regresinya harus berdistribusi normal. Uji linearitas bertujuan untuk mengetahui apakah dua variabel yang akan diteliti mempunyai hubungan yang linear secara signifikan atau tidak. Sedangkan uji heteroskedastisitas atau homogenitas varians dilakukan hanya untuk meyakinkan bahwa variasi skor dari ketiga variabel bersifat homogen.

\section{Uji Normalitas Galat Taksiran}

Uji normalitas galat taksiran harus dilakukan sebagai persyaratan analisis. Uji normalitasnya dilakukan terhadap galat taksiran $\mathrm{Y}$ atas $\mathrm{X} 1, \mathrm{Y}$ atas $\mathrm{X} 2$ dan $\mathrm{Y}$ atas $\mathrm{X} 1$ dan $\mathrm{X} 2$.

${ }^{25}$ Ronny Kountor. (2007). Metode Penelitian Untuk Penulisan Skripsi dan Tesis. Jakarta: PPM. hlm.161. 
Uji Normalitas Galat Taksiran Regresi Y (Prestasi Akademik) atas X1 (Program Tahfidzul Qur'an) dan X2 (Motivasi Belajar) baik secara sendirisendiri maupun secara simultan pada mahasiswa PKD dan PKP Universitas Djuanda Bogor. Hasil pengujian normalitas galat taksiran diperoleh tabel sebagai berikut:

\begin{tabular}{|c|c|c|c|c|}
\hline \multicolumn{5}{|c|}{ One-Sample Kolmogorof-Smirnov Test } \\
\hline & & $\begin{array}{c}\text { Residual } \\
\text { regresi } Y \\
\text { atas } X 1\end{array}$ & $\begin{array}{c}\text { Residual } \\
\text { regresi } Y \\
\text { atas } X 2\end{array}$ & $\begin{array}{c}\text { Residual } \\
\text { regresi } Y \\
\text { atas X1 \& } \\
\text { X2 }\end{array}$ \\
\hline & $\mathrm{N}$ & 104 & 104 & 104 \\
\hline \multirow[t]{2}{*}{ Normal Parameters ${ }^{\mathrm{a}, \mathrm{b}}$} & Mean & 121,09 & 102.83 & 3.2918 \\
\hline & Std. Deviation & 15.482 & 9.247 & .41605 \\
\hline \multirow[t]{5}{*}{ Most Exstreme Differences } & Absolute & .060 & .059 & .090 \\
\hline & Positive & .060 & .059 & .083 \\
\hline & Negative & -0.058 & -0.049 & -0 \\
\hline & Kolmogorov-Smirnov Z & 611 & .602 & 922 \\
\hline & Asymp. Sig, (2-tailed) & .849 & .861 & .363 \\
\hline \multicolumn{5}{|c|}{ a. Test distribution is Normal } \\
\hline \multicolumn{5}{|c|}{ b. Calculated from data. } \\
\hline
\end{tabular}

Berdasarkan tabel di atas diperoleh nilai p (Asymp. Sig. (2 tailed)) diperoleh untuk residual regresi $\mathrm{Y}$ atas $\mathrm{X} 1$ sebesar 0,849 dan residual regresi $\mathrm{Y}$ atas $\mathrm{X} 2$ sebesar 0,861 nilai-nilai ini lebih besar dari 5\% maka hipotesis nol diterima, artinya galat taksiran persamaan regresi $\mathrm{Y}$ atas $\mathrm{X} 1$ dan $\mathrm{Y}$ atas $\mathrm{X} 2$ berdistribusi normal, sedangkan residual regresi $\mathrm{Y}$ atas $\mathrm{X} 1$ dan X2 sebesar 0,363 nilai ini lebih kecil dari $5 \%$ maka hipotesis nol ditolak, artinya galat taksiran persamaan regresi $\mathrm{Y}$ atas $\mathrm{X} 1$ dan $\mathrm{X} 2$ berdistribusi tidak normal.

\section{Uji Hipotesis}

Pengujian hipotesis dalam penelitian bertujuan untuk menguji tiga hipotesis yang telah dirumuskan yaitu:

Terdapat hubungan positif antara program Tahfidzul Qur'an dengan prestasi akademik mahasiswa PKD dan PKP, (2) Terdapat hubungan yang positif antara motivasi belajar dengan prestasi akademik mahasiswa PKD dan PKP, dan (3) Terdapat hubungan yang positif secara bersama-sama antara program Tahfidzul Qur'an dan motivasi belajar dengan prestasi akademik mahasiswa PKD dan PKP.

Berdasarkan hasil uji persyaratan ternyata pengujian hipotesis dapat dilakukan sebab sejumlah persyaratan yang ditentukan untuk pengujian hipotesis, seperti normalitas, linieritas dan homogenitas dari data yang diperoleh telah dapat dipenuhi. Pengujian hipotesis ini dilakukan dengan menggunakan analisis korelasi dan regresi secara sederhana dan ganda.

\section{a. Hubungan Antara Program Tahfidzul Qur'an $\left(\mathrm{X}^{1}\right)$ dengan Prestasi Akademik Mahasiswa PKD dan PKP (Y)}

Hipotesis pertama yang diuji dalam penelitian ini menyatakan bahwa 
terdapat hubungan antara Program

Tahfidzul Qur'an $\left(\mathrm{X}^{1}\right)$ dengan Prestasi

Akademik Mahasiswa PKD dan PKP (Y).

Tabel Koefesien untuk Regresi Linear sederhana

$$
\hat{Y}=0,007+2,490 X^{1}
$$

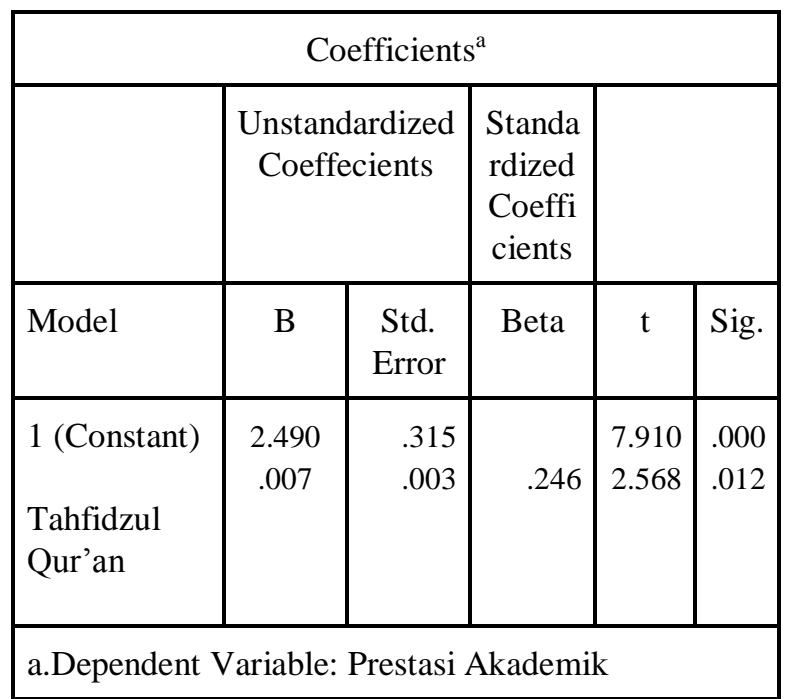

Analisis regresi linier sederhana terhadap penelitian hubungan antara program Tahfidzul Qur'an $\left(\mathrm{X}^{1}\right)$ dengan prestasi akademik mahasiswa PKD dan PKP (Y)menghasilkan koefisien arah b sebesar 0,007 dan konstanta sebesar 2,490 Dengan demikian bentuk hubungan antara kedua variable tersebut dapat disajikan oleh persamaan regresi $\hat{Y}=0,007+2,490 X^{1}$.

Persamaan tersebut dapat diartikan bahwa apabila skor program Tahfidzul Qur'an atau $\mathrm{X}^{1}$ naik 1 poin maka akan diikuti oleh prestasi akademik (Y) sebesar 0,007 poin.

Untuk mengetahui derajat signifikansinya, maka persamaan regresi tersebut selanjutnya diuji dengan menggunakan uji-F. Adapun hasilnya seperti tertera dalam tabel analisis varian di bawah ini.

Tabel Anova untuk Regresi Linear sederhana

$$
\hat{Y}=0,007+2,490 X^{1}
$$

\begin{tabular}{|l|r|r|r|c|c|}
\hline \multicolumn{7}{|c|}{ ANOVA $^{\mathrm{b}}$} \\
\hline Model & $\begin{array}{l}\text { Sum of } \\
\text { Squares }\end{array}$ & df & $\begin{array}{c}\text { Mean } \\
\text { Square }\end{array}$ & F & Sig. \\
\hline 1 & 1.083 & 1 & 1.083 & 6.594 & $.012^{\mathrm{a}}$ \\
Regression & & & & \\
\hline \multicolumn{6}{|c|}{$\begin{array}{l}\text { a. Predictors: (Constant), Tahfidzul Qur'an } \\
\text { b. Dependent Variable: Prestasi Akademik }\end{array}$} \\
\hline
\end{tabular}

Berdasarkan hasil analisis varians di atas, ternyata nilai $\mathrm{p}$ (sig.) $=0,012$ nilai lebih kecil dari 5\% maka hipotesis nol ditolak, hal ini berarti bahwa koefisien regresi di atas sangat signifikan. Dengan demikian dapat disimpulkan bahwa persamaan regresi $\mathrm{Y}=0,007+2,490 \mathrm{X}^{1}$ yang diperoleh adalah signifikan.

Jika divisualisasikan maka hubungan antara antara program Tahfidzul Qur'an $\left(\mathrm{X}^{1}\right)$ dengan prestasi akademik mahasiswa 
PKD dan PKP (Y) dengan persamaan regresi $\mathrm{Y}=0,007+2,490 \mathrm{X}^{1}$ akan tampak seperti gambar dibawah ini.

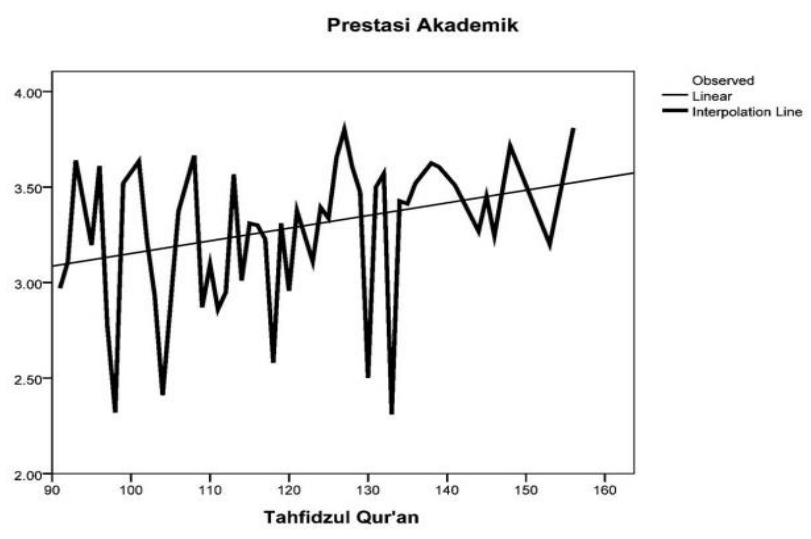

Gambar. Hubungan Linear antara

Program Tahfidzul Qur'an dengan Prestasi Akademik

Selanjutnya analisis korelasi antara program Tahfidzul Qur'an dengan prestasi akademik mahasiswa PKD dan PKP diperoleh nilai koefisien korelasi (derajat keeratan hubungan) seperti dibawah ini.
Berdasarkan tabel nilai koefisien korelasi di atas, analisis hubungan/korelasi terhadap pasangan-pasangan data dari kedua variabel tersebut menghasilkan koefisien korelasi $r$ product-moment sebesar 0,246.

Telaah signifikansi terhadap nilai koefisien korelasi tersebut diperoleh nilai $\mathrm{p}$ $=0,006$. Karena nilai $\mathrm{p}<5 \%$ berarti hipotesis nol ditolak, hal ini menunjukkan bahwa nilai koefisien korelasi antara program Tahfidzul Qur'an dengan prestasi akademik mahasiswa adalah signifikan. Artinya terdapat hubungan positif dan cukup erat antara program Tahfidzul Qur'an dengan prestasi akademik mahasiswa PKD dan PKP Universitas Djuanda Bogor.

\begin{tabular}{|r|r|r|}
\hline \multicolumn{3}{|c|}{ Correlation } \\
\hline & \multicolumn{1}{|c|}{ Tahfidzul Qur'an } & Prestasi Akademik \\
\hline $\begin{array}{l}\text { Tahfidzul Qur'an Pearson } \\
\text { Correlation }\end{array}$ & 1 & $.246^{*}$ \\
Sig. (2- tailed) & 104 & .012 \\
& & 104 \\
\hline $\begin{array}{l}\text { Prestasi Akademik Pearson } \\
\text { Correlation }\end{array}$ & $.246^{*}$ & 1 \\
Sig. (2- tailed) & .012 & 104 \\
\hline N Correlation is significant at the level (2-tailed) \\
\hline
\end{tabular}


Selanjutnya koefesien korelasi $r$ dapat dilihat dalam tabel berikut;

\begin{tabular}{|c|c|c|c|c|c|}
\hline \multicolumn{6}{|c|}{ Coefficients $^{\mathrm{a}}$} \\
\hline & \multicolumn{2}{|c|}{$\begin{array}{c}\text { Unstandardize } \\
\text { d } \\
\text { Coeffecients }\end{array}$} & $\begin{array}{l}\text { Standardi } \\
\text { zed } \\
\text { Coefficie }\end{array}$ & & \\
\hline Model & B & $\begin{array}{l}\text { Std. } \\
\text { Error }\end{array}$ & Beta & $\mathrm{t}$ & Sig. \\
\hline $\begin{array}{l}1 \\
\text { (Consta } \\
\text { nt) } \\
\text { Motiva } \\
\text { si } \\
\text { Belajar }\end{array}$ & $\begin{array}{r}1.81 \\
1 \\
.014\end{array}$ & $\begin{array}{l}.436 \\
.004\end{array}$ & .320 & $\begin{array}{r}4.15 \\
6 \\
3.41 \\
3\end{array}$ & $\begin{array}{l}.000 \\
.001\end{array}$ \\
\hline
\end{tabular}

Tabel Koefesien Korelasi "r" antara Program Tahfidzul Qur'an dengan Prestasi Akademik Mahasiswa

\begin{tabular}{|c|c|c|c|}
\hline \multicolumn{4}{|c|}{ Model Summary } \\
\hline R & $\begin{array}{l}\text { R } \\
\text { Squar } \\
\text { e }\end{array}$ & $\begin{array}{c}\text { Adjuste } \\
\text { d R } \\
\text { Square }\end{array}$ & $\begin{array}{c}\text { Std. Error } \\
\text { of } \\
\text { The } \\
\text { Estimate }\end{array}$ \\
\hline .246 & .061 & .052 & .405 \\
\hline \multicolumn{3}{|c|}{ The independent variable is Tahfidzul } \\
Qur'an
\end{tabular}

Karena koefisien korelasi $\mathrm{r}=0,246$, maka dapat diperoleh nilai koefisien determinasinya sebesar $\mathrm{R}^{2}=0,061$ yang berarti bahwa 6,1 \% variansi prestasi akademik mahsiswa PKD dan PKP Universitas Djuanda Bogor dapat dipengaruhi oleh program Tahfidzul Qur'an melalui persamaan regresi : $\mathrm{Y}=0,007+$ $2,490 X^{1}$

Dengan kata lain kontribusi program Tahfidzul Qur'an terhadap Prestasi Akademik Mahasiswa PKD dan PKP sebesar $6,1 \%$ sedangkan sisanya 93,9\% dipengaruhi oleh faktor lainnya.

\section{b. Hubungan Antara Motivasi Belajar $\left(\mathrm{X}^{2}\right)$ dengan Prestasi Akademik Mahasiswa PKD dan PKP (Y)}

Hipotesis kedua yang diuji dalam penelitian ini menyatakan bahwa terdapat hubungan antara motivasi Belajar $\left(\mathrm{X}^{2}\right)$ dengan prestasi akademik mahasiswa PKD dan PKP (Y).

Tabel Koefesien untuk Regresi

$$
\begin{gathered}
\text { Linear sederhana } \\
\hat{Y}=0,014+1,811 \mathrm{X}^{2}
\end{gathered}
$$

Analisi regresi linier sederhana terhadap penelitian hubungan antara motivasi belajar $\left(\mathrm{X}^{2}\right)$ dengan prestasi akademik mahasiswa PKD dan PKP (Y) menghasilkan koefisien arah $b$ sebesar 0,014 dan konstanta sebesar 1,811 Dengan demikian bentuk hubungan antara kedua variable tersebut dapat disajikan oleh persamaan regresi $\hat{Y}=0,014+1,811 \mathrm{X}^{2}$.

Persamaan tersebut dapat diartikan bahwa apabila skor motivasi belajar atau $\mathrm{X}^{2}$ naik 1 poin maka akan diikuti oleh prestasi akademik (Y) sebesar 0,014 poin 
Untuk mengetahui derajat signifikansinya, maka persamaan regresi tersebut selanjutnya diuji dengan menggunakan uji-F. Adapun hasilnya seperti tertera dalam tabel analisis varians di bawah ini.

Tabel 5.4.9 untuk Regresi Linear Sederhana

$\hat{Y}=0,014+1,811 X^{2}$

\begin{tabular}{|l|r|r|r|r|r|}
\hline \multicolumn{6}{|c|}{ ANOVA $^{\mathrm{b}}$} \\
\hline Model & $\begin{array}{c}\text { Sum of } \\
\text { Squares }\end{array}$ & df & $\begin{array}{c}\text { Mean } \\
\text { Square }\end{array}$ & F & Sig. \\
\hline $\begin{array}{l}\text { 1Regress } \\
\text { ion }\end{array}$ & 1.827 & 1 & 1.827 & 11 & .001 \\
.6 & \\
& & & & \\
\hline
\end{tabular}

a. Predictors: (Constant), Motivasi

Belajar

b. Dependent Variable: Prestasi Akademik

Berdasarkan hasil analisis varians di atas, ternyata nilai $\mathrm{p}$ (sig.) $=0,001$ nilai lebih kecil dari 5\% maka hipotesis nol ditolak, hal ini berarti bahwa koefisien regresi di atas sangat signifikan. Dengan demikian dapat disimpulkan bahwa persamaan regresi $\mathrm{Y}=0,014+1,811 \mathrm{X}^{2}$ yang diperoleh adalah signifikan.

Jika divisualisasikan maka hubungan antara antara Motivasi Belajar $\left(\mathrm{X}^{2}\right)$ dengan Prestasi Akademik Mahasiswa
PKD dan PKP (Y) dengan persamaan regresi $\mathrm{Y}=0,014+1,811 \mathrm{X}^{2}$ akan tampak seperti gambar dibawah ini.

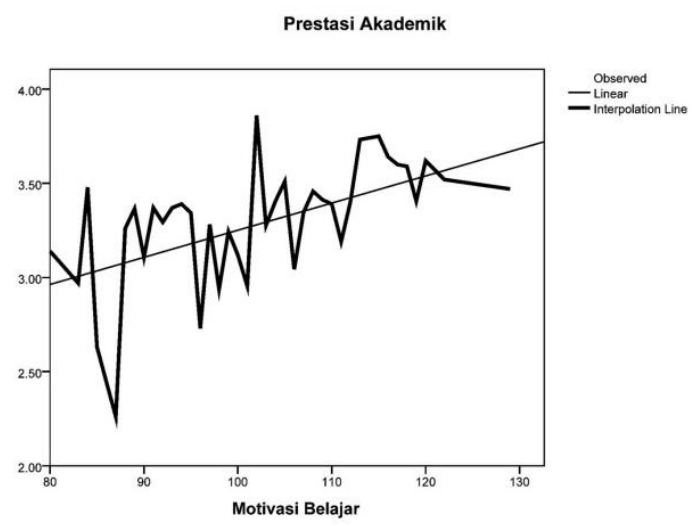

Gambar. Hubungan Linear antara Motivasi Belajar dengan Prestasi Akademik

Selanjutnya analisis korelasi antara Motivasi Belajar dengan Prestasi Akademik Mahasiswa PKD dan PKP diperoleh nilai koefisien korelasi (derajat keeratan hubungan) seperti dibawah ini.

Tabel Koefesien Korelasi antara Motivasi Belajar dengan Prestasi Akademik Mahasiswa 


\begin{tabular}{|l|r|r|}
\hline \multicolumn{3}{|c|}{ Correlation } \\
\hline & $\begin{array}{r}\text { Motiva } \\
\text { si } \\
\text { Belajar }\end{array}$ & $\begin{array}{c}\text { Prestasi } \\
\text { Akademik }\end{array}$ \\
\hline $\begin{array}{l}\text { Motivasi Belajar } \\
\text { Pearson Correlation }\end{array}$ & 1 & $.320^{*}$ \\
.001 \\
104 \\
Sig. (2- tailed) & 104 & \\
\hline Prestasi Akademik & $.320^{*}$ & \\
Pearson Correlation & .001 & 1 \\
Sig. (2- tailed) & 104 & 104 \\
\hline N*. Correlation is significant at the level \\
(2-tailed)
\end{tabular}

Berdasarkan tabel nilai koefisien korelasi di atas, analisis hubungan/korelasi terhadap pasangan-pasangan data dari kedua variabel tersebut menghasilkan koefisien korelasi $\mathrm{r}$ product-moment sebesar 0,320 .

Telaah signifikansi terhadap nilai koefisien korelasi tersebut diperoleh nilai $\mathrm{p}$ $=0,000$. Karena nilai $\mathrm{p}<5 \%$ berarti hipotesis nol ditolak, hal ini menunjukkan bahwa nilai koefisien korelasi antara motivasi belajar dengan prestasi akademik mahasiswa adalah signifikan. Artinya terdapat hubungan positif dan cukup erat antara motivasi belajar dengan prestasi akademik mahasiswa PKD dan PKP Universitas Djuanda Bogor.
Selanjutnya koefesien korelasi $r$

dapat dilihat dalam tabel berikut; Tabel Koefesien Korelasi " $r$ " antara Motivasi Belajar dengan Prestasi Akademik Mahasiswa

\begin{tabular}{|c|r|r|r|}
\hline \multicolumn{5}{|c|}{ Model Summary } \\
\hline $\mathrm{R}$ & $\begin{array}{l}\mathrm{R} \\
\text { Square }\end{array}$ & $\begin{array}{l}\text { Adjusted R } \\
\text { Square }\end{array}$ & $\begin{array}{c}\text { Std. Error of } \\
\text { The Estimate }\end{array}$ \\
\hline .320 & .102 & .094 & .396 \\
\hline The independent variable is Motivasi Belajar \\
\hline
\end{tabular}

Karena koefisien korelasi $\mathrm{r}=0,320$ maka dapat diperoleh nilai koefisien determinasinya sebesar $\mathrm{R}^{2}=0,102$ yang berarti bahwa 10,2 \% variansi prestasi akademik mahsiswa PKD dan PKP Universitas Djuanda Bogor dapat dipengaruhi oleh motivasi belajar melalui persamaan regresi : $\mathrm{Y}=0,014+1,811 \mathrm{X}^{2}$. Dengan kata lain kontribusi motivasi belajar terhadap prestasi akademik mahasiswa PKD dan PKP sebesar 10,2 \% sedangkan sisanya 89,8\% dipengaruhi oleh karena faktor lainnya.

\section{c. Hubungan Antara Program Tahfidzul Qur'an $\left(\mathrm{X}^{\mathbf{1}}\right)$ dan Motivasi Belajar $\left(\mathrm{X}^{2}\right)$ secara bersama-sama dengan Prestasi Akademik Mahasiswa PKD dan PKP (Y)}

Hipotesis ketiga yang diuji dalam penelitian ini menyatakan bahwa terdapat hubungan antara program Tahfidzul Qur'an ( $\left.\mathrm{X}^{1}\right)$ dan motivasi belajar $\left(\mathrm{X}^{2}\right)$ secara bersama-sama 
terhadap prestasi akademik mahasiswa PKD dan PKP (Y).

Analisi regresi linier sederhana terhadap penelitian hubungan antara program Tahfidzul Qur'an (X $\left.{ }^{1}\right)$ dan motivasi belajar $\left(\mathrm{X}^{2}\right)$ dengan prestasi akademik mahasiswa PKD dan PKP dapat dilihat pada tabel berikut ini;

Tabel Koefesien untuk Regresi Linear sederhana

$$
\hat{Y}=1,727+0,003 X^{1}+0,012 X^{2}
$$

\begin{tabular}{|c|c|c|c|c|c|}
\hline \multicolumn{6}{|c|}{ ANOVA $^{b}$} \\
\hline Model & $\begin{array}{l}\text { Sum of } \\
\text { Squares }\end{array}$ & df & $\begin{array}{c}\text { Mean } \\
\text { Square }\end{array}$ & $\mathrm{F}$ & Sig. \\
\hline 1 & 1.970 & 2 & .985 & 6.27 & .003 \\
\hline Regressi & 15.859 & 101 & .157 & 4 & $\mathrm{a}$ \\
\hline on & 17.829 & 103 & & & \\
\hline Residual & & & & & \\
\hline Total & & & & & \\
\hline
\end{tabular}

a. Predictors: (Constant), Motivasi Belajar, Tahfidzul Qur'an

b. Dependent Variable: Prestasi Akademik

Analisi regresi linier sederhana terhadap penelitian hubungan antara program Tahfidzul Qur'an dan motivasi belajar dengan prestasi akademik menghasilkan koefisien arah B1 sebesar 0,003, koefisien arah B2 sebesar 0,012, dan konstanta B0 sebesar 1,727. Dengan demikian bentuk hubungan ketiga variable tersebut dapat disajikan oleh persamaan regresi $\hat{Y}=1,727+0,003 X^{1}+0,012 X^{2}$.

Persamaan tersebut dapat diartikan bahwa apabila program Tahfidzul Qur'an
$\left(\mathrm{X}^{1}\right)$ dan Motivasi Belajar $\left(\mathrm{X}^{2}\right)$ masingmasing naik satu poin atau satu skor, maka akan diikuti oleh prestasi akademik mahasiswa PKD dan PKP (Y) sebesar 0,015 poin.

Untuk mengetahui derajat signifikansinya, maka persamaan regresi tersebut selanjutnya diuji dengan menggunakan uji-F. Adapun hasilnya seperti tertera dalam tabel analisis varians di bawah ini:

Tabel Anova untuk Regresi Linear sederhana

$$
\hat{Y}=1,727+0,003 X^{1}+0,012 X^{2}
$$

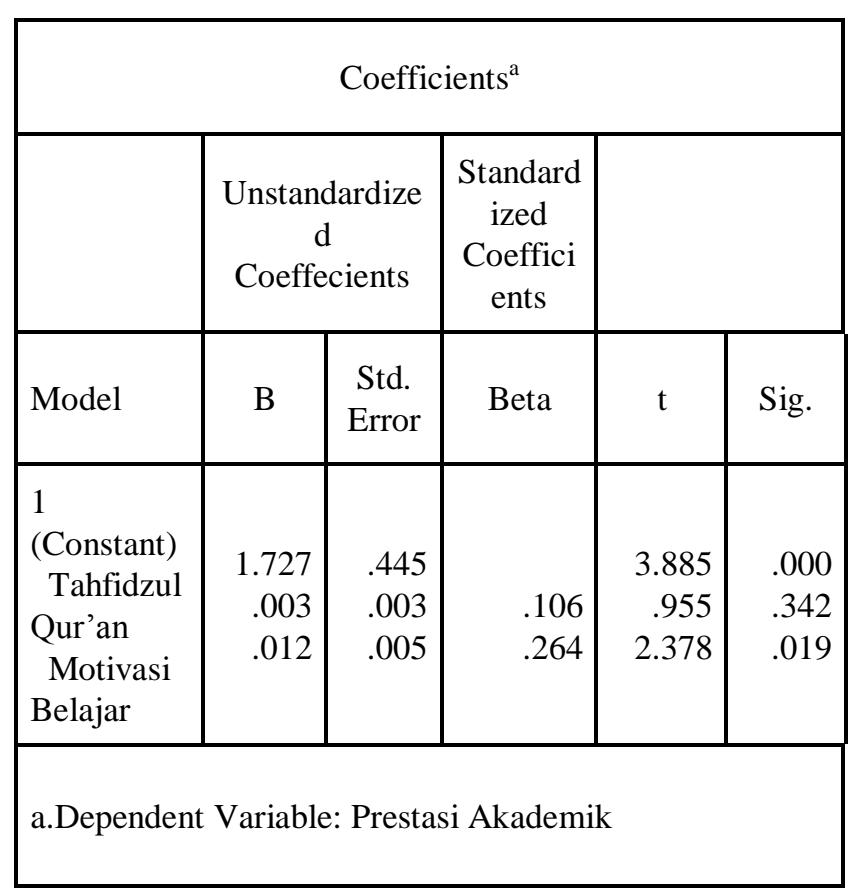

Berdasarkan hasil analisis varians di atas, ternyata nilai $\mathrm{P}=0,000$. Nilai ini lebih kecil dari $\alpha=5 \%$ atau nilai $F$ hitung: 13 , 064 lebih besar dari $\mathrm{F}(0,05)(6,274)=3,17$, maka tolak $\mathrm{H}_{0}$, berarti koefisien regresi di atas adalah signifikan.

Selanjutnya analisis korelasi program Tahfidzul Qur'an dan motivasi belajar dengan prestasi akademik mahasiswa PKD dan PKP diperoleh hasil sebagai berikut: 
Tabel Koefesien Korelasi "r" antara Program tahfidzul Qur'an dan Motivasi

Belajar dengan Prestasi Akademik Mahasiswa

\begin{tabular}{|l|r|r|c|c|}
\hline \multicolumn{5}{|c|}{ Model Summary $^{\mathrm{b}}$} \\
\hline $\begin{array}{l}\text { Mo } \\
\text { del }\end{array}$ & $\mathrm{R}$ & R Square & $\begin{array}{c}\text { Adjusted } \\
\mathrm{R} \\
\text { Square }\end{array}$ & $\begin{array}{c}\text { Std. Error of } \\
\text { The } \\
\text { Estimate }\end{array}$ \\
\hline 1 & .3 & .111 & .093 & .39626 \\
& $\begin{array}{r}32 \\
\mathrm{a}\end{array}$ & & & \\
\hline
\end{tabular}

a. Predictor: (Constant), Motivasi Belajar, Tahfidzul Qur'an

b. Dependent Variable: Prestasi Akademik

Berdasarkan tabel di atas, analisis korelasi terhadap pasangan-pasangan data dari ketiga variabel tersebut menghasilkan koefisien korelasi $\mathrm{r}$ product-moment sebesar 0,332. Telaah signifikansi terhadap nilai koefisien korelasi tersebut diperoleh nilai $\mathrm{P}=0,000$. Karena nilai $\mathrm{P}<5 \%$ berarti $\mathrm{H}_{0}$ ditolak, hal ini menunjukkan bahwa nilai koefisien korelasi antara Program Tahfidzul Qur'an dan motivasi belajar mahasiswa dengan prestasi akademik mahasiswa PKD dan PKP adalah signifikan. Artinya terdapat hubungan positif dan sedang antara program Tahfidzul Qur'an dan motivasi belajar dengan presatasi akademik mahasiswa.

Selanjutnya karena koefisien korelasi $\mathrm{r}$ product-moment $=0,332$, maka dapat diperoleh nilai koefisien determinasinya $\left(\mathrm{R}^{2}\right)$ sebesar $=0,111$ yang berarti bahwa $11,1 \%$ variansi prestasi akademik mahasiswa PKD dan PKP dapat dijelaskan oleh program Tahfidzul Qur'an dan motivasi belajar melalui persamaan regresi $\hat{Y}=1,727+0,003 X^{1}+0,012 X^{2}$.

Dengan kata lain kontribusi variable program Tahfidzul Qur'an dan motivasi belajar terhadap prestasi akademik mahasiswa sebesar $11,1 \%$, sedangkan sisanya $88,9 \%$ karena faktor lainnya.

\section{Pembahasan Hasil Penelitian}

Berdasarkan data yang diperoleh dari hasil penelitian kemudian diolah dengan menggunakan perangkat lunak SPSS for windows versi 17.0, dapat dijadikan sebagai dasar untuk menjawab hipotesis yang diajukan yaitu adanya "Hubungan program Tahfidzul Qur'an dan motivasi belajar dengan Prestasi Akademik Mahasiswa PKD dan PKP" baik secara sendiri-sendiri maupun simultan (bersama-sama).

Beberapa faktor yang mendukung keberhasilan Prestasi akademik sebagaimana pada pembahasan bab sebelumnya, maka beberapa faktor yang dikemukakan di atas merupakan faktorfaktor yang baik secara langsung maupun tidak langsung memiliki hubungan dengan keberhasilan Prestasi akademik setiap mahasiswa. Penelitian ini mencoba mencari hubungan antara beberapa faktor internal dan beberapa faktor eksternal dalam proses pembelajaran yang dianggap paling berpengaruh terhadap keberhasilan 
mahasiswa yaitu program Tahfidzul Qur'an dan motivasi belajar mahasiswa PKD dan PKP Universitas Djuanda Bogor yaitu;

\section{Hubungan Antara Program} Tahfidzul Qur'an $\left(X^{1}\right)$ dengan Prestasi Akademik Mahasiswa PKD dan PKP (Y)

Hipotesis nol $\left(\mathrm{H}^{0}\right)$ yang menyatakan tidak terdapat hubungan positif antara program Tahfidzul Qur'an (X $\left.{ }^{1}\right)$ dengan prestasi akademik mahasiswa PKD dan PKP Universitas Djuanda Bogor (Y) melawan hipotesis alternatif $\left(\mathrm{H}^{1}\right)$ yang menyatakan terdapat hubungan positif antara program Tahfidzul Qur'an (X $)$ dengan prestasi akademik mahasiswa PKD dan PKP Universitas Djuanda Bogor (Y), pengujian tersebut dengan menggunakan teknik analisis regresi dan korelasi sederhana.

Dari uji hipotesis ditemukan bahwa terdapat hubungan yang positif dan rendah antara Program Tahfidzul Qur'an dengan prestasi akademik mahasiswa PKD dan PKP. Hubungan ini dinyatakan dengan persamaan, $\hat{\mathrm{Y}}=0,007+2,490 \mathrm{X}^{1}$.

Berdasarkan persamaan tersebut diperoleh hasil koefisien regresi untuk variabel program Tahfidzul Qur'an dan prestasi akademik mahasiswa PKD dan PKP adalah sebesar 0,007.

Uji hipotesisi antara program Tahfidzul Qur'an dengan Prestasi akademik mahasiswa PKD dan PKP menghasilkan koefisien korelasi $\mathrm{r}=0,246$ maka dapat diperoleh nilai koefisien determinasinya sebesar $\mathrm{R}^{2}=0,061$ yang berarti bahwa 6,1 \% variansi prestasi akademik mahsiswa PKD dan PKP Universitas Djuanda Bogor dapat dipengaruhi oleh program Tahfidzul Qur'an melalui persamaan regresi : $\mathrm{Y}=$ $0,007+2,490 X^{1}$. Dengan kata lain kontribusi program Tahfidzul Qur'an terhadap prestasi akademik mahasiswa PKD dan PKP sebesar 6,1 \% sedangkan sisanya 93,9 \% dipengaruhi oleh karena faktor lainnya.

Kontribusi program Tahfidzul Qur'an sebesar 6,1\% menunjukkan bahwa sebuah program Tahfidzul Qur'an yang di program secara baik dan maksimal akan memicu prestasi akademik mahasiswa PKD dan PKP Universitas Djuanda Bogor.

Program Tahfidzul Qur'an yang baik/tinggi merupakan faktor pendorong bagi peningkatan prestasi akademik mahasiswa, sehingga mereka bisa lebih berprestasi dalam belajarnya. Untuk itu para dewan pembina mahasiswa PKD dan PKP Universitas Djuanda Bogor senantiasa meningkatkan intensitas program Tahfidzul Qur'an dengan maksimal, sehingga para mahasiswa PKD dan PKP termotivasi lebih tinggi untuk meningkatkan prestasi akademiknya. 
2. Hubungan Antara Motivasi Belajar $\left(\mathrm{X}^{2}\right)$ dengan Prestasi Akademik Mahasiswa PKD dan PKP (Y)

Hipotesis nol $\left(\mathrm{H}^{0}\right)$ yang menyatakan tidak terdapat hubungan positif antara motivasi belajar $\left(\mathrm{X}^{2}\right)$ dengan prestasi akademik mahasiswa PKD dan PKP Universitas Djuanda Bogor (Y) melawan hipotesis alternatif $\left(\mathrm{H}^{\mathrm{I}}\right)$ yang menyatakan terdapat hubungan positif antara motivasi belajar $\left(\mathrm{X}^{2}\right)$ dengan prestasi akademik mahasiswa PKD dan PKP Universitas Djuanda Bogor (Y), pengujian tersebut dengan menggunakan teknik analisis regresi dan korelasi sederhana.

Dari uji hipotesis ditemukan bahwa terdapat hubungan yang positif dan sedang antara motivasi belajar dengan prestasi akademik mahasiswa PKD dan PKP. Hubungan ini dinyatakan dengan persamaan, $\hat{\mathrm{Y}}=0,014+1,811 \mathrm{X}^{2}$.

Berdasarkan persamaan tersebut diperoleh hasil koefisien regresi untuk variabel motivasi belajar dan prestasi akademik mahasiswa PKD dan PKP adalah sebesar 0,014 .

Uji hipotesis antara motivasi belajar dengan prestasi akademik mahasiswa PKD dan PKP menghasilkan koefisien korelasi sebesar $\mathrm{r}=0,320$ maka dapat diperoleh nilai koefisien determinasinya sebesar $\mathrm{R}^{2}=$ 0,102 yang berarti bahwa 10,2\% variansi Prestasi Akademik Mahsiswa PKD dan
PKP Universitas Djuanda Bogor dapat dipengaruhi oleh motivasi belajar melalui persamaan regresi : $\mathrm{Y}=0,014+1,811 \mathrm{X}^{2}$. Dengan kata lain kontribusi motivasi belajar terhadap prestasi akademik mahasiswa PKD dan PKP sebesar 10,2 \% sedangkan sisanya 89,8\% dipengaruhi oleh karena faktor lainnya.

Kontribusi Motivasi Belajar sebesar $10,2 \%$ menunjukkan bahwa sebuah motivasi belajar yang di program secara baik dan maksimal akan memicu prestasi akademik mahasiswa PKD dan PKP Universitas Djuanda Bogor.

3. Hubungan Antara Program Tahfidzul Qur'an $\left(X^{1}\right)$ dan Motivasi Belajar $\left(\mathbf{X}^{2}\right)$ dengan Prestasi Akademik Mahasiswa PKD dan PKP (Y)

Hipotesis nol $\left(\mathrm{H}^{0}\right)$ yang menyatakan tidak terdapat hubungan positif antara program Tahfidzul Qur'an $\left(\mathrm{X}^{1}\right)$ dan motivasi belajar $\left(\mathrm{X}^{2}\right)$ secara bersama-sama dengan prestasi akademik mahasiswa PKD dan PKP Universitas Djuanda Bogor (Y) melawan hipotesis alternatif $\left(\mathrm{H}^{\mathrm{I}}\right)$ yang menyatakan terdapat hubungan positif antara program Tahfidzul Qur'an $\left(\mathrm{X}^{1}\right)$ dan motivasi belajar $\left(\mathrm{X}^{2}\right)$ secara bersama-sama dengan prestasi akademik mahasiswa PKD dan PKP Universitas Djuanda Bogor (Y), pengujian tersebut dengan menggunakan 
teknik analisis regresi dan korelasi sederhana.

Dari hasil perhitungan analisis regresi linear berganda antara program Tahfidzul Qur'an dan motivasi belajar dengan Prestasi Akademik Mahasiswa PKD dan PKP Uiversitas Djuanda Bogor diperoleh persamaan regresi yaitu $\hat{\mathrm{Y}}=1,727+0,003$ $X^{1}+0,012 X^{2}$.

Dari persamaan tersebut maka dapat diartikan bahwa satu-satuan skor prestasi akademik mahasiswa PKD dan PKP akan dipengaruhi oleh program Tahfidzul Qur'an sebesar 0,003 dan motivasi belajar sebesar 0,012 pada konstanta 1,727 .

Hasil koefesien regresi untuk variabel program Tahfidzul Qur'an sebesar 0,003. Harga koefesien regresi yang bertanda positif menunjukkan bahwa hubungan program Tahfidzul Qur'an dengan prestasi akademik ada hubungan positif dan rendah, yang artinya setiap terjadi kenaikan satu skor program Tahfidzul Qur'an, maka akan diikuti dengan meningkatnya prestasi akademik mahasiswa sebesar 0,003.

Hasil koefesien regresi untuk variabel motivasi belajar sebesar 0,012. Harga koefesien regresi yang bertanda positif menunjukkan bahwa hubungan motivasi belajar dengan prestasi akademik ada hubungan positif dan sedang, yang artinya setiap terjadi kenaikan satu skor motivasi belajar, maka akan diikuti dengan meningkatnya prestasi akademik mahasiswa sebesar 0,012 .

\section{Kesimpulan}

Dari hasil penelitian yang telah dilakukan, dapat diambil kesimpulan sebagai berikut:

a. Hasil koefesien regresi untuk variabel program Tahfidzul Qur'an sebesar 0,003. Harga koefesien regresi yang bertanda positif menunjukkan bahwa hubungan program Tahfidzul Qur'an dengan prestasi akademik ada hubungan positif dan rendah, yang artinya setiap terjadi kenaikan satu skor program Tahfidzul Qur'an, maka akan diikuti dengan meningkatnya prestasi akademik mahasiswa sebesar 0,003 .

b. Hasil koefesien regresi untuk variabel motivasi belajar sebesar 0,012. Harga koefesien regresi yang bertanda positif menunjukkan bahwa hubungan motivasi belajar dengan prestasi akademik ada hubungan positif dan sedang, yang artinya setiap terjadi kenaikan satu skor motivasi belajar, maka akan diikuti dengan meningkatnya prestasi Aakademik mahasiswa sebesar 0,012 . 


\section{Daftar Pustaka}

Arikunto, S. (2002). Prosedur Penelitian Suatu Pendekatan Praktek. Jakarta: PT Rineka Cipta.

Chalil, M. Kembali Kepada Al-Quran dan As-Sunnah. Jakarta: Bulan Bintang, t.t.

Departemen Pendidikan dan Kebudayaan. (1995). Kamus Besar Bahasa Indonesia. Jakarta: Balai Pustaka: cet. IV.

Departemen Agama RI. (2008). Al-Qur'an dan Terjemahnya. Jakarta: Depag RI.

Djamarah, S.B. (1994). Prestasi Belajar Dan Kompetensi Guru. Surabaya: UsahaNasional.

Harahap, S. (2006). Penegakan Moral Akademik Didalam dan Luar Kampus. Jakarta: Raja Grafindo.

Ibn Mājah. (1998). Sunan Ibnu Mājah. Kairo: Dar al-Kutub.

Iskandar. (2009). Metodologi Penelitian Pendidikan dan Sosial (Kualitatif dan Kuantitatif. Jakarta: Gaung Persada Press.

Kementerian Agama RI. (2010). Al-Qur'an dan Tafsirnya. Ciawi: LPQ Kemenag RI.

Margono, S. (2004). Metodologi Penelitian Pendidikan. Jakarta: Rineka Cipta.

Maslow, A. (1954). Motivation and Personality. New York: Harper \& Row.

McClelland, David. C. (1961). The Achieving Society. New York: Van Nostrand Reinhold.

Nawabuddin, A. dan Bambang, S.M. (2005). Teknik Menghafal Al-Quran. Bandung: Sinar Baru Algensindo.
Pusat Pembinaan dan Pengembangan Bahasa Depdikbud. (1989). Kamus Besar Bahasa Indonesia. Jakarta: Balai Pustaka.

Qattan, M. al-. Mabāḥist fì 'ulūm alQur'ān, Libanon: Dar el-Kutub tt.

Ranupandojo dan Husnan. (1990). Psikologi Motivasi. Yogyakarta: LKIS.

Sa'dulloh. (2009). Sembilan Cara Praktis Menghafal Al-Qur'an. Depok: Gema Insani Press.

Sudjana. (1996). Metode Statistika. Bandung: Penerbit Tarsito.

Suryabrata. (2002). Sumadi Psikologi Pendidikan. Jakarta: PT Raja Grafindo.

(2008). Metodologi penelitian. Jakarta: PT Raja Grafindo Persada.

Sukardi. (2003). Metodologi Penelitian Pendidikan. Jakarta: Bumi Aksara.

Syah, M. (2000). Psikologi Pendidikan dengan Pendekatan Baru. Bandung: Remaja Rosdakarya.

Jakarta: Logos.

Slameto. (1988). Belajar dan Faktor-faktor Yang Mempengaruhinya. Jakarta: Bina Aksara.

Sugiyono. (2006). Metode Penelitian Kuantitatif Kualitatif dan $R \& D$. Bandung: Alfabeta.

Tatiana, Endang dan Budi W. S. Model Prestasi Akademik Mahasiswa: Potensi Akademik dan Gaya Belajar. Jurnal USAHAWAN. 04 (2005). 
Warson, A. (1997). Kamus Al-Munawwir Edisi kedua, Surabaya: Pustaka Progressif.

Zen, Muhaimin. (1998). Tata Cara Problematika Menghafal Al-Quran dan Petunjuk-petunjuknya. Jakarta: Litera Antar Nusa.

(2012). Metode Pengajaran

Tahfidz Al-Qur'an di pondok
Pesantren, Tsanawiyah, Aliyah dan Perguruan Tinggi. Jakarta: Percetakan Online.

http://musiconlinecairo.multiply.com/journ al

http://wwwbruderfic.or.id

http://www.unida.ac.id 